\title{
Júbilo y fuga de Emilio Ballagas
}

ARgyll PRYOR Rice

ESDE la dicotomía del título fluyen las dos límpidas corrientes de 1 Júbilo y fuga, ${ }^{1}$ corrientes que ora se distinguen claramente la una de la otra, ora se mezclan en júbilo fugaz o en fuga jubilosa. Son varias y muy personales las formas que toma el júbilo de Emilio Ballagas. Lo vislumbramos en las arcanas regiones de la creación poética y lo presenciamos en la germinación del mundo adánico del poeta. Comienza en el éxtasis del estado prenatal de "Víspera", el primer poema del libro, donde yace ingénito, en la unión perfecta del germen, poeta-poesía:

Estarme aqui quieto, germen

de la canción venidera

-íntegro, virgen, futuro.

Estarme dormido -intimo-

en tierno latir ausente

de honda presencia secreta.

$\mathrm{Y}$ éxtasis —alimento-

de ignorarme - ausente, puro-

nonnato de claridades

con la palabra inicial

y el dulce mañana intacto.

Ausente del tiempo, libre de su dominio, el poeta lo ve "dulce" e "intacto". Envuelto en las claridades del éxtasis, duerme su estro íntegro,

1 Emilio Ballagas, Obra poética de Emilio Ballagas. La Habana, 1955. Edición póstuma con un ensayo preliminar de Cintio Vitier. 
latiendo en ritmos perfectos y líricas sugerencias. Se siente la presencia de la fuerza creadora, hecha de pulsaciones transparentes, en el momento antes de entrar en los confines de la palabra. Es la poesía virgen, antes de sus bodas con la materia.

Desde tres puntos de vista Ballagas poetiza aquella región de la poesía pura de Henri Bremond. En "Víspera", la sentimos en el éxtasis prenatal; en "Júbilo de la ola", el poeta, ya nacido, vuelve a encontrarla en el silencio interior; y en "Inicial del sueño", Ballagas está en camino al ensueño, o sea, a la región de la poesía pura. Como las burbujas que sueña y mira volar y huir, se fuga hacia un ámbito de iridiscencias.

Las pulsaciones de arcanas regiones del ser y del no-ser adquieren ímpetu. El perderse y esconderse más allá de la subconsciencia lleva al júbilo de comenzar, terna que llega hasta el título de algunos poemas: "Empezar", "Nacer", "Inicial" e "Inicial del sueño". Y de ahí verbos como resbalar, volar, buir, vagar y fugarse que prestan movimiento tanto al mundo interior del sueño como al camino hacia él. Es ligera, sin embargo, la fuga hacia adentro porque la fuerza motriz del libro es otra. El éxtasis del "nonnato de claridades", la ola del silencio y "la luz blanca" del sueño, son aproximaciones a la región de la creación poética, la fuente de toda acción que siempre está iniciando un sinfín de diminutos orígenes centelleantes. Es insistente en Júbilo y fuga el girar de esta fuerza centrífuga.

El poeta sabe captar el momento de equilibrio antes de actuar. Declara en "Empezar": "Soy una gota de rocío trémula/en el pétalo fresco de la aurora"; y dentro del lucero de "Nacer", la prístina lágrima es una nota clara que anuncia el llanto venidero: "En la entraña del lucero/ canta mi lágrima clara". El llanto es, por consiguiente, claridad envuelta en claridad, libre de la angustia en el estado ideal.

En Júbilo y fuga Ballagas poetiza los sentidos en su máxima intensidad. Sabe destilarlos, intelectualizarlos y darlos como ingrávidas esencias a la espuma de su verso. Siempre libres de lo pasional y agudos en el momento antes de que la vida los embote, se estrenan autónomos como si se descubtieran a sí mismos. Tal sencillez brota de complejos procesos de una sensibilidad exacerbada en relación con una inteligencia atrevida y dúctil.

La plenitud del deleite sensual hay que buscarla en el poema titulado sencillamente "Sentidos": 
iQue me cierren los ojos con uvas!

(Diáfana, honda plenitud de curvas.)

Que me envuelva un incendio de manzanas

y un claro rumor de dátil y azúcar!

Que me envuelvan - presagio de pulpa-

en ciruelas de tacto perfumado...

Inundadme

en pleamar de pétalos y trinos.

Que me ciñan -iceñidme! - de eclípticas azules.

Aunque Ballagas nombra solamente la vista y el tacto, están aquí presentes todos los sentidos. El "claro rumor de dátil y azúcar", sinestesia rara y eficaz, atrae tanto el oído como el gusto, y en las "ciruelas de tacto perfumado" se enlazan el gusto, el tacto y el olfato. Como el oído es implícito en rumor y el olfato en prerfumado, así se sugiere el gusto en los vocablos azuicar, mas, manzanas, dátil y ciruelas. Estos substantivos llevan doble función. Además de ofrecer suculentas sugerencias al paladar, proporcionan gratos efectos plásticos a la vista. Las ciruelas y el "incendio de manzanas" calientan y avivan de colores los versos, mientras que las uvas, con su "diáfana, honda plenitud de curvas", y las "eclípticas azules" envuelven al poeta en generosas líneas ondulantes y círculos de cósmica plenitud.

El poeta tiene grandes anhelos de perderse en pleno éxtasis sensual y lo busca por medio de imperativos y subjuntivos. Los subjuntivos de las tres primeras estrofas y la repetición del verbo envolver sirven de fondo para que el cambio al imperativo y el uso de un verbo más dinámico inundar intensifiquen la expresión de ansia. La última estrofa de un solo verso, que combina tanto el subjuntivo como el imperativo del mismo verbo ceñir, termina el poema en una nota cosmológica. Los verbos cerrar, envolver, inundar y ceñitr señalan el empeño emocional a la unión total hasta el punto de un anonadamiento, que, más que muerte, deja la impresión de metempsicosis al Sentido mismo.

Inmaculado queda el sensualismo de Juibilo y fuga. El anhelado éxtasis no es el de la pasión, sino más bien el del júbilo asociado a la infancia, tema ligado a los del nacimiento de los sentidos y de la incipiencia en general. La cualidad paradisíaca de la infancia se extiende por 
todo el libro de Ballagas y, como ángel de la guarda, vela por la castidad de este cuaderno.

Es el júbilo de la niñez, límpida y edénica, lo que inspira a Emilio a cantar:

Todavía yo siento este gozo inefable de ser niño; de sentir en mis venas correr ell sol, la espuma de su luz. Todavía cantan mis manos y a la tarde lanzo un júbilo de gritos sin historia.

Todavía yo guardo este gozo infantil de sentir nuevo el pétalo, de apretar en los labios besos por estrenar...

Todavía al soplar el caramillo joven a mis pies apaciento un tebaño de sueños.

("Gozo")

Aquí los besos están en la condición ideal antes de ser consumidos por la realidad, y hasta el poeta niño no tiene raíces en la realidad biológica. En vez de sangre, siente correr por sus venas la alegría del sol en espuma de luz. Tan intenso es el júbilo que se hace físico y se desborda en "un júbilo de gritos". La sintaxis normal, "gritos de júbilo", hubiera limitado júbilo a una función cualitativa, pero al invertir el orden a "un júbilo de gritos", el poeta le añade un significado cuantitativo y así intensifica el poder de la imagen. Es un júbilo fugaz de canciones "sin historia", recién nacidas, que guardan toda la frescura del gozo infantil. El pastorcillo poeta cuida los sueños, origen de tales canciones, y los canta en la música de su "caramillo joven".

De las manos con lo infantil va el espíritu de juego, y en el poema titulado "Los ecos", se combinan de manera curiosa el juego y la fuga. Bajo la mano del poeta mago, los ecos cobran luz y sustancia. Ya modelados en goma luminosa, estos fantasmas de sonidos buscan salida de una noche "cuadrada" a otra noche esférica, perfecta, eterna. Luego el poeta suelta sus sentidos, "bestezuelas" juguetonas, a asaltat estos "plenilunios" de ilusión en un juego de júbilo fugaz. Con los sentidos, pues, Ballagas pone en juego el tiempo, el espacio, la luz y la sustancia, insigne ejemplo 
éste de la "realización júbilosa" y la "gimnasia intelectual" que el poeta llamaba "los misterios gozosos" de su verso."

$\mathrm{El}$ color, igual que la luz, ilumina e irisa Júbilo y fuga. Aunque Ballagas usa colores específicos (verde, por ejemplo, para indicar lo tiernamente joven e inocente), más que colores individualizados le interesa el racimo de colores que procede en arco iris de la luz refractada. En "Perfección del Sï", que trata de las pluralidades dentro de la unidad, Ballagas trae al primer plano el acto prismático:

Con los colores del Quiero

en la inquietud - pentagrama-

una escala me improviso:

do re mi fa sol la si...

El hacer una escala con colores recuerda a Artur Rimbaud, quien dio color a los sonidos vocálicos, pero es más profundo e intenso el concepto ballagueano. En una escalla improvisada de música colorida se mueve inquieto el Quiero, voz que abarca la gama del anhelo. El poeta que experimenta visual y auditativamente las partes componentes del Quiero total, se detiene en si, la última nota, que sirve de punto de partida para otro sí:

$$
\begin{aligned}
& \text { Y con la unidad del Sí } \\
& \text {-curva afirmativa, esfera- } \\
& \text { albura, luz perfectísima, } \\
& \text { me crearé un arcoiris: } \\
& \text { malva, rosa, verde, azul... }
\end{aligned}
$$

El si, de uso frecuente en el "lenguaje generacional" de los poetas puros, es palabra central en la poesía de Jorge Guillén, donde indica un mundo perfecto o la aceptación de la vida. Aunque con el mundo perfecto de Guillén tiene evidente afinidad el $S \dot{z}$ de Ballagas, éste le trae una nota original al concebir dentro de la unidad del Sí metempsicosis musical igual que pluralidades coloridas. "Perfección del Sî" es una afirmación jubilosa de lo absoluto, de la esfera de perfección. Es "albura, luz perfectísima" que por medio del prisma poético se irisa, hecha todo un arco iris de colores diversos. La última estrofa reúne en el Si la luz refractada con la luz primaria:

2 Ballagas, "La poesía en mî", en Revista Cubana, La Habana, 1937, Vol. IX, Nự. 26, p. 160 . 


\section{Intima policromía \\ del Sí, perfecta luz blanca.}

Resulta ser "íntima policromía" porque dentro del poeta la "perfecta luz blanca" del Sí se prismatiza en íntimas experiencias poéticas. En 1937 el poeta ha de decir: "Dispongo de unos cuantos colores puros o soy un prisma que echa a volar en siete canciones las secretas aves de la luz perfecta". 3

La compenetración de color y música aparece también en una imagen de "Las alegrías". En "Perfección del Sin", el poeta hace una escala de siete colores, y aquí, ya hecha la escala, sus alegrías le cantan una ronda inédita de múltiples colores. Presenciamos el origen de las alegrías en cierne que, primaverales y cternas, nacen cantando en la sangre del poeta. Bien equilibrada con el regocijo al nacer el júbilo mismo, es la fuga que en este poema toma dos formas. Hay las fugas todavía nonatas que Emilio quiere estrenar, y hay la fuga del viento que lleva consigo los trinos de alegrías en altas fugas jubilosas.

Como de varias maneras se manifiesta el júbilo, se presenta la fuga como camaleón que cambia su matiz según las circunstancias. En "Huir", por ejemplo, es una fuga loca en que el poeta trata de escaparse del tiempo y del espacio. En su poema titulado "Fuga", el poeta trata de alcanzar la eternidad cogiendo el tiempo, pero se le escapa por no posecr el Verbo en donde tiene su vida el instante que Ballagas llama "eternidad en fuga".

La fuga en relación con lo eterno es tema también del hermoso poema "Viento de la luz de junio":

Llévame por donde quieras, viento de la luz de junio, -remolino de lo eterno.

¿Adónde?

Si ya he ido, si ya vuelvo.

Si ya nada quiero, nada;

ni lo que tengo, ni aquello

que estuve soñando ayer.

Ahora por no querer y no saber lo que quiero lo quiero todo... ¡Qué júbilo!

3 Ibid., p. 158, 
¿Qué beato ahogarse en tu oleaje!

Soy como un niño que estrena

la pura emoción del Quiero.

¡Ay, la espuma, lo lejano

$\mathrm{y}$ aquellas voces, naranjas

-tacto, color y fragancia-

que se mecen en las frondas

como sorpresas redondas!

Llévame adonde tú quieras

- tú me ciñes, tú me vences-

que ahora me rindo dócil,

a tu voluntad viajera,

luz de jugar y de huir...

Llévame, llévame, llévame

a secuestrarme en lo eterno

-ansia, oleaje, grupa, crin-

viento de la luz de junio.

Junio es el pleno mediodía del año, el mediodía de la luz, la luz mística cuyo viento es el "remolino de lo eterno". El deseo del poeta también está en su plenitud. Ya no es el querer del pasado o del presente limitado en el tiempo por un objeto específico, sino el no-querer, el querer al revés que es el único que le queda. Este no-querer, sin embargo, es afirmativo, el más afirmativo de todos. Precisamente por ignorar su objeto, tiene anhelos de poseerlo todo. Es el deseo completo, pues, que nace del júbilo de haberse rendido a una voluntad superior. Con un "ay", el poeta se despide de los objetos de su quiero parcial y entrega "la pura emoción" de su "Quiero" total a la "voluntad viajera" de la "luz de jugar y de huir", origen de todo júbilo y fuga. Ya no huye el poeta de lo finito ni persigue el tiempo inalcanzable; más bien se pone dúctil en la fuga del "remolino de lo eterno".

El ligero movimiento de la brisa y de la espuma igual que la plena fuga del viento y de "remotos soles" han entretejido por todo este cuaderno con el júbilo de comienzos, sentidos, inocencia de la infancia y el juego. No hay, sin embargo, un dinamismo ascendente desde ligeras pero insistentes pulsaciones prenatales hasta tápidos vuelos de fugas siderales. 
Más bien está la intensidad de la fuerza centrífuga en continua oscilación espontánea.

Aunque aparecen en Júbilo y fuga sombras fatídicas de portentosas negruras, el aliento de este cuaderno es otro. La pluma de Emilio Ballagas escribe dejando fresco el verso y las huellas sombrías en nada menguan la alegría. Claridades de fuente recóndita emanan de las palabras e iluminan las imágenes. Esto no quiere decir, sin embargo, que sea poesía fácil. Por esto dice Jorge Mañach en una reseña scbre la "poesía ultraindividualizada" de Júbilo y fuga que "lo característico de este tipo de poesía no es su intención sino su contención: no es el sentido que despliega sino el sentido que encierra y que a menudo esconde". No es, pues, poesía para aquellos filisteos que no comprenden la lógica que puede haber en lo alógico y que se marean en presencia del desequilibrio equilibrado. De las arcanas regiones de la creación poética oímos cantar al poeta felizmente desarraigado de la tierra filistea: "Y yo canto desnudo,/ alimentado de mi raíz en vilo"." Al renunciar a los lugares comunes, Emilio Ballagas crea en Júbilo y fuga sus propias vías, su propio mundo paradisíaco de la eterna poesía y desde el "nonnato de claridades" presencia su propio nacimiento a ese mundo edénico.

ARgYLI PRYOR RICE

Connecticut College

4. "Canto sin márgenes", poena inédito. 